\title{
Weathering of Petroleum Biomarkers: Review in Tropical Marine Environment Impacts
}

\author{
Claudia Y. Reyes*, Ícaro T. A. Moreira, Daiane A. F. Oliveira, Naijane C. Medeiros, \\ Marcos Almeida, Fernanda Wandega, Sarah A. R. Soares, Olívia M. C. de Oliveira \\ Núcleo de Estudos Ambientais-Instituto de Geociências, Universidade Federal da Bahia, Campus Universitário \\ de Ondina, Salvador, Brasil \\ Email: ${ }^{*}$ chemiyores@yahoo.com
}

Received 14 October 2014; revised 23 November 2014; accepted 10 December 2014

Copyright (C) 2014 by authors and OALib.

This work is licensed under the Creative Commons Attribution International License (CC BY). http://creativecommons.org/licenses/by/4.0/

(c) †) Open Access

\begin{abstract}
Weathering of biomarkers is a physical, geochemical and biological process that alters the oil components. Whether in petroleum geochemistry or environmental impact studies, knowledge of mechanisms, residence times and chemical intermediates is essential to describe the scientific and technical bases of oil deterioration. This report attempts to review the concepts of oil weathering and its biomarkers specifically, in order to inform studies related to the impact of spills in marine environments.
\end{abstract}

Keywords

Gammacerane, $\mathrm{C}_{30}$-Hopane, Steranes, $\mathrm{PAH}$, Crude Oil, Marine Environment Impacts, Oil Degradation

Subject Areas: Environmental Sciences, Geochemistry

\section{Introduction}

Petroleum is the non-renewable natural resource most used by humans. Many industrial activities use petroleum as energy source or raw material for thousands of substances and products of daily use [1]-[4]. Fossil fuel deposits are not equally distributed on the globe, but its demand is high especially in most industrialized countries, so the international transport across the world is required mainly by ship. Consequently, this excessive consumption of oil generates negative impacts on humans and environment, indirectly, either by $\mathrm{CO}_{2}$ emissions, or directly, by possible crude oil spills and/or its derivatives [5] [6].

*Corresponding author.

How to cite this paper: Reyes, C.Y., Moreira, Í.T.A., Oliveira, D.A.F., Medeiros, N.C., Almeida, M., Wandega, F., Soares, S.A.R. and Oliveira, O.M.C. (2014) Weathering of Petroleum Biomarkers: Review in Tropical Marine Environment Impacts. Open Access Library Journal, 1: e1004. http://dx.doi.org/10.4236/oalib.1101004 
Weathering, is a natural defense mechanism in ecosystems [5] [6], and it acts like the main remediation process for areas affected by the components of crude oil [7]-[10]. Knowledge of the residence time, weathering and degradation routes of a particular type of petroleum provides relevant information concerning the remediation process in case of spills [10]-[14]. The most recent studies report the mechanisms involved in degradation of oil, and it is well known that each type of oil has unique steps in its degradative process. They are not only associated with the physicochemical characteristics of the oil, but also highly influenced by the bio-physicalgeochemical factors around the impacted area [1] [10] [14]-[18].

In exploration geochemistry, weathering is one of the factors that influence the quality of the stored oil in reservoirs [1]-[3] [7] [9] [19]-[21]. Weathering begins acting in depositional environment, during burial, influencing the quality of kerogen [2] and also promoting the "oxidation" of the residual kerogen (inertinite type) which is feasible and gas source. In the reservoirs, weathering processes are responsible for the loss of light components of oil, generating an increase of heavy fractions and viscosity and a decrease of fluidity, which make the oil difficult to be recovered [1]-[9] [16] [22]-[25].

This manuscript proposes a review, about the weathering of biomarker of petroleum and the parameters frequently used to monitor and evaluate this process, for different types of crude oil.

\section{Weathering Process}

Weathering is regulated by physical, chemical and biological processes, which act on the geological material throughout time and depend on the nature of the environment in which such material is introduce [5] [14] [19]. The interaction between these processes and the geological material generates a weathered product, i.e., the geological material and mass modified [26]. The petroleum compounds, such as hydrocarbons, biomarkers and other substances [3] [20] [27], can also be weathered, degraded or altered physical and geochemically by biotic and abiotic factors [1] [18] [28] [29] still in the reservoir rock, during the processes of exploration and/or transport and possible spills [5] [12].

Petroleum weathering in marine environments [15] [19] [22] [30] [31] (or involving water as means physical contact) includes processes like adsorption, biodegradation [23], dispersion, dissolution, emulsification, spreading, evaporation, photo-oxidation (Table 1) [1] [5] [12] [32] acting synergistically, decomposing, deteriorating, oxidizing or weathering the crude oil (Figure 1) [1] [33]-[40]. There is also a special case of adsorption processes, were the oil or his derivatives aggregate on the material particles suspended in the column water, called OSA (Suspended Particulate Material Oil-Aggregates).

The time and intensity of action of each process can differ and depend mainly on the physical and geochemical characteristics of the oil spilled [1] [10]. Thus, each phenomenon depends intrinsically on the pre-existence of other to promote the degradation or attenuation of an oil patch in the environment [12] [15] [29] [41].

The physico-chemical characteristics of oil can change depending on its stage of maturation or degradation. The American Petroleum Institute (API) has established a standard hydrometric scale (API gravity) to classify the oils and its derivatives [41]. The API gravity is a physical property that relates the density and the fluidity of a crude oil. This property is directly related to their geochemical composition, which will directly influence the weathering processes and the residence time of a given oil into the ecosystem. The Figure 2 presents the behavior for different kind of petroleum. For example, for light crude oils, with higher API gravity (Group 1), present a short weathering time, which reach no more than some weeks. However, in oils with low API gravity, less than 25 (Group 4), the weathering time can take decades because the predominance of fractions of higher chemical complexity and molecular weights, such as resins and asphaltenes, which are practically unalterable by weathering processes, and cause, therefore, a significant environmental impact [1] [5] [19] [26] [31] [42] [43].

The Table 2 present a classification for different oils, according to their density (API gravity) and composition for some international agencies related to the oil industry.

\section{Biomarkers}

Geochemical biomarkers, also known as molecular markers or geochemical fossils, are complex and stable organic molecules, which is present in oils and can be analyzed, identified and quantified [1] [44]. These molecules are derived from the cell membrane of alive organisms (prokaryotic or eukaryotic), so they are called precursor and have a high degree of specificity [45]. The similarity between biomarkers and their precursor molecules (synthesized by alive organisms) and the relation between different biomarkers provide information about 
Table 1. Weathering process associated with the oil spill in marine environments.

\begin{tabular}{|c|c|c|c|}
\hline Process & Type & Mechanism and/or Reaction & Effect \\
\hline Adsorption & Physical-chemical & Electrostatic interactions & $\begin{array}{l}\text { Adhesion of oil components to suspended particulate } \\
\text { matter and OSA [5] [36]. }\end{array}$ \\
\hline Biodegradation & Biochemical & $\begin{array}{l}\text { Oxidation/decomposition by } \\
\text { microorganisms }\end{array}$ & $\begin{array}{l}\text { Modification of physical-chemical properties of } \\
\text { molecules [1] [5] [11] [17] [31] [36]. }\end{array}$ \\
\hline Dispersion & Physical & Water turbulence & Break-up the oil patch into droplets [5] [36]. \\
\hline Dissolution & Physical-chemical & $\begin{array}{l}\text { Water temperature and } \\
\text { turbulence }\end{array}$ & $\begin{array}{l}\text { Solubilization of petroleum compounds, especially } \\
\text { those with low molecular weight and size [5] [36]. }\end{array}$ \\
\hline Emulsification & Physical-chemical & $\begin{array}{l}\text { Water temperature and } \\
\text { turbulence }\end{array}$ & $\begin{array}{l}\text { Formation of double or triple emulsions, i.e., tiny oil } \\
\text { droplets (disperse phase) in water (continuous phase), } \\
\text { forming a metastable mixture [5] [36]. }\end{array}$ \\
\hline Spreading & Physical & $\begin{array}{l}\text { Action of winds, tides, waves } \\
\text { and currents }\end{array}$ & $\begin{array}{l}\text { Oil patch expansion. If the petroleum has light } \\
\text { composition, the spread of the patch is easier [5] [36]. }\end{array}$ \\
\hline Evaporation & Physical-chemical & $\begin{array}{l}\text { Water temperature and } \\
\text { turbulence }\end{array}$ & Volatilization of oil compounds [1] [5] [36]. \\
\hline Photo-oxidation & Physical-chemical & $\begin{array}{l}\text { Action of light, especially } \\
\text { ultraviolet radiation, and oxygen }\end{array}$ & $\begin{array}{l}\text { Break oil constituents in simple molecules [1] [5] [32] } \\
\text { [36]. }\end{array}$ \\
\hline
\end{tabular}

Table 2. API gravity classification by different world agencies.

\begin{tabular}{|c|c|c|c|c|}
\hline \multirow{2}{*}{ Agency } & \multicolumn{4}{|c|}{ Grau API } \\
\hline & Light & Medium & Heavy & Ultra Heavy \\
\hline Alberta Government/Canada ${ }^{1}$ & $\geq 34.0$ & $25.0-34.0$ & $10.0-25.0$ & $\leq 10.0$ \\
\hline US Deparment of Energy ${ }^{2}$ & $\geq 35.1$ & $25.0-35.1$ & $10.0-25.0$ & $\leq 10.0$ \\
\hline $\begin{array}{l}\text { Organization of the Petroleum Exporting } \\
\text { Countries (OPEC) })^{3}\end{array}$ & $\geq 32.0$ & $26.0-32.0$ & $10.5-26.0$ & $\leq 10.5$ \\
\hline Petrobras Offshore ${ }^{4}$ & $\geq 32.0$ & $19.0-32.0$ & $14.0-19.0$ & $\leq 14.0$ \\
\hline Petrobras Onshore $^{4}$ & $\geq 32.0$ & $18.0-32.0$ & $13.0-18.0$ & $\leq 13.0$ \\
\hline ANP/Brasil ${ }^{5}$ & $\geq 31.1$ & $22.3-31.1$ & $12.0-22.3$ & $\leq 12.0$ \\
\hline Americam Petroleum Institute (API) ${ }^{6}$ & $\begin{array}{c}\geq 30.0 \\
\text { Basically } 15 \% \\
\text { alkanes and } 25 \% \\
\text { alkanes cycle }\end{array}$ & $\begin{array}{l}22.0 \text { - } 30.0 \\
\text { Alkanes and } 25 \% \text { to } \\
\text { 30\% hydrocarbons }\end{array}$ & $\begin{array}{c}10.0-22.0 \\
\text { Aromatic } \\
\text { hydrocarbons }\end{array}$ & $\begin{array}{c}\leq 10.0 \\
\text { Long chain } \\
\text { hydrocarbons } \\
\text { (higher than pentane) }\end{array}$ \\
\hline
\end{tabular}

Source: 1: Governo do Estado de Alberta, Canada, http://www.gov.ab.ca; 2: Departamento de Energia dos Estados Unidos, http://www.energy.gov; 3: OPEC (Organization of the Petroleum Exporting Countries), http://www.opec.org; 4: Petróleos Brasileiros S. A., http://www.petrobras.com.br; 5: Agência Nacional de Petróleo, http://www.anp.gov.br; 6: American Petroleum Institute, http://www.api.org.

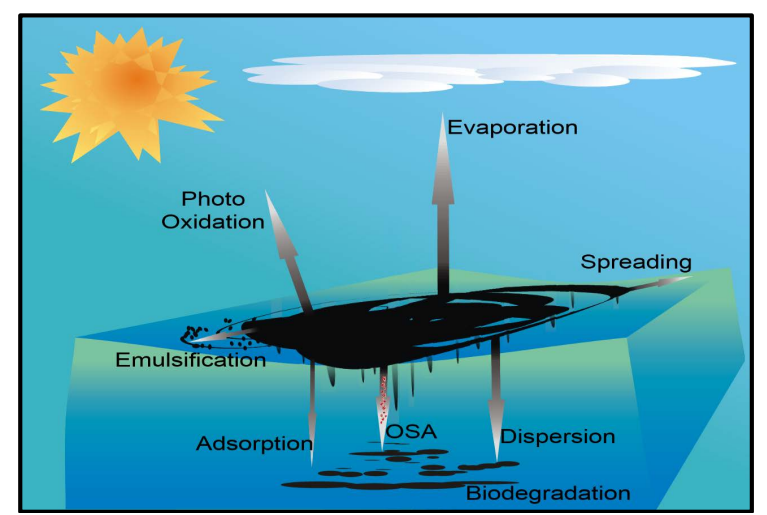

Source: Modified from No. 6 Fuel Oil (Bunker C) Spills, NOAA’s National Ocean Service, 2006.

Figure 1. Weathering process associated to petroleum spill in marine environment. 


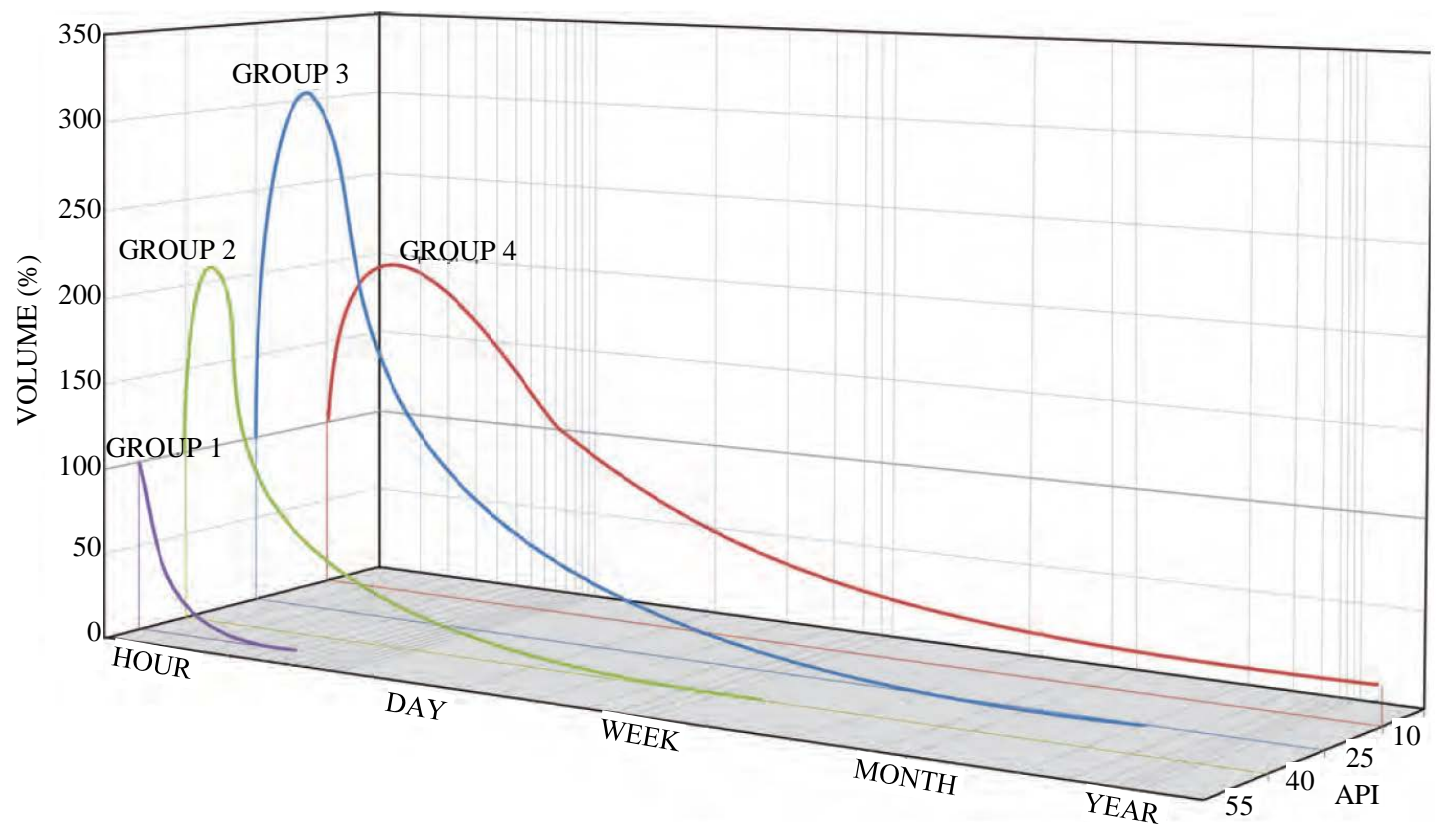

Source: http://www.itopf.com/marine-spills/fate/models/index.html, 2014.

Figure 2. Residence time of petroleum in marine environment according to its API grade.

the organic matter source, paleo environmental characteristics, thermal evolution degree, oil identification (fingerprint) and rock-oil, oil-oil and rock-rock ratio [46]-[48]. However, the separated information is not absolutely reliable; it requires the largest number of possible relations to obtain a good interpretation [1] [9] [28] [31] [44] [45] [49]-[51].

Therefore, petroleum biomarkers are the components of most geochemical interest because they allow to define the factors genetics of each oil [1] [22] [23] [47] [52]. The petroleum biomarkers more commonly used in geochemistry are branched, cyclic and alkylated cyclicalkanes, like pristane $\left(\mathrm{C}_{19} ; 2,6,10,14\right.$-tetramethylpen-tadecane) and phytane $\left(\mathrm{C}_{20} ; 2,6,10,14\right.$-tetramethyl hexane), for acyclic alkanes [1]. Cyclic saturated biomarkers include tricyclic, tetracyclic as the $\mathrm{C}_{27}, \mathrm{C}_{28}$ and steranes $\mathrm{C}_{29}$ (cholestane, ergostane and stigmastane respectively, so-called diamondoid). Pentacyclics [53], such as $\mathrm{C}_{30}$-hopane, are the most abundant biomarkers in oil, and they are followed by gammacerane, the homologous series of homohopanes and norhopanes $\left(T_{s}, T_{m}\right)$ [18] [54] [55], and others [1] (Table 3).

Molecules of biological origin such as biomarkers exhibit stereoisomerism [1] [7] [9] [54] [55], i.e., isomers exhibit same formula and molecular weight, but differ in spatial arrangements of their atoms [55]. The same occurs for homologous series of petroleum biomarkers, which present isomers $\mathrm{S}, \mathrm{R}, \alpha \alpha \alpha, \alpha \beta \beta, \beta \beta \beta$, for hydrogen bound to a particular(s) carbon(s) in the biomarker. These variations are according to their origin, geochemical maturity degree or degradation level [1] [54] [56] [57]. The $\mathrm{C}_{29}$ sterane epimers are examples; they are used as paleotemperature or geochemical maturity parameters (Figure 3) [57]. In environmental geochemistry, stereoisomerism can be used to estimate degradation level (weathering) of crude oil or assessing remediation processes in areas impacted by petroleum activities [1] [9] [10] [44].

Another important petroleum biomarker is chemically classified as aromatic hydrocarbon [1] [8], can be use as indicators of input of organic matter, to assess the maturity level or environmental applications, or also to assess the source and composition of these compounds in a contaminated ecosystem [1] [56] [58]. Geochemically the poliaromatic hydrocarbon (PAH) may have different sources [59]. When originate from incomplete combustion processes and include molecules with up to six aromatic rings, the source is called pyrolytic. Petrogenic source correspond to aromatic compounds of higher molecular weight and it includes the pyrolytic. Due to the PAHs physicochemical characteristics, they are considered priority pollutant substances by global control agencies [56] [59] (Table 4). According to the classification and the legislative rules, hydrocarbons with 16 or 32 aromatic hydrocarbons should be monitored, because some of them can be carcinogenic and very dangerous for human healthy and the environmental. 
Table 3. Examples of tricyclic, tetracyclic, and pentacyclic saturated biomarkers [1].

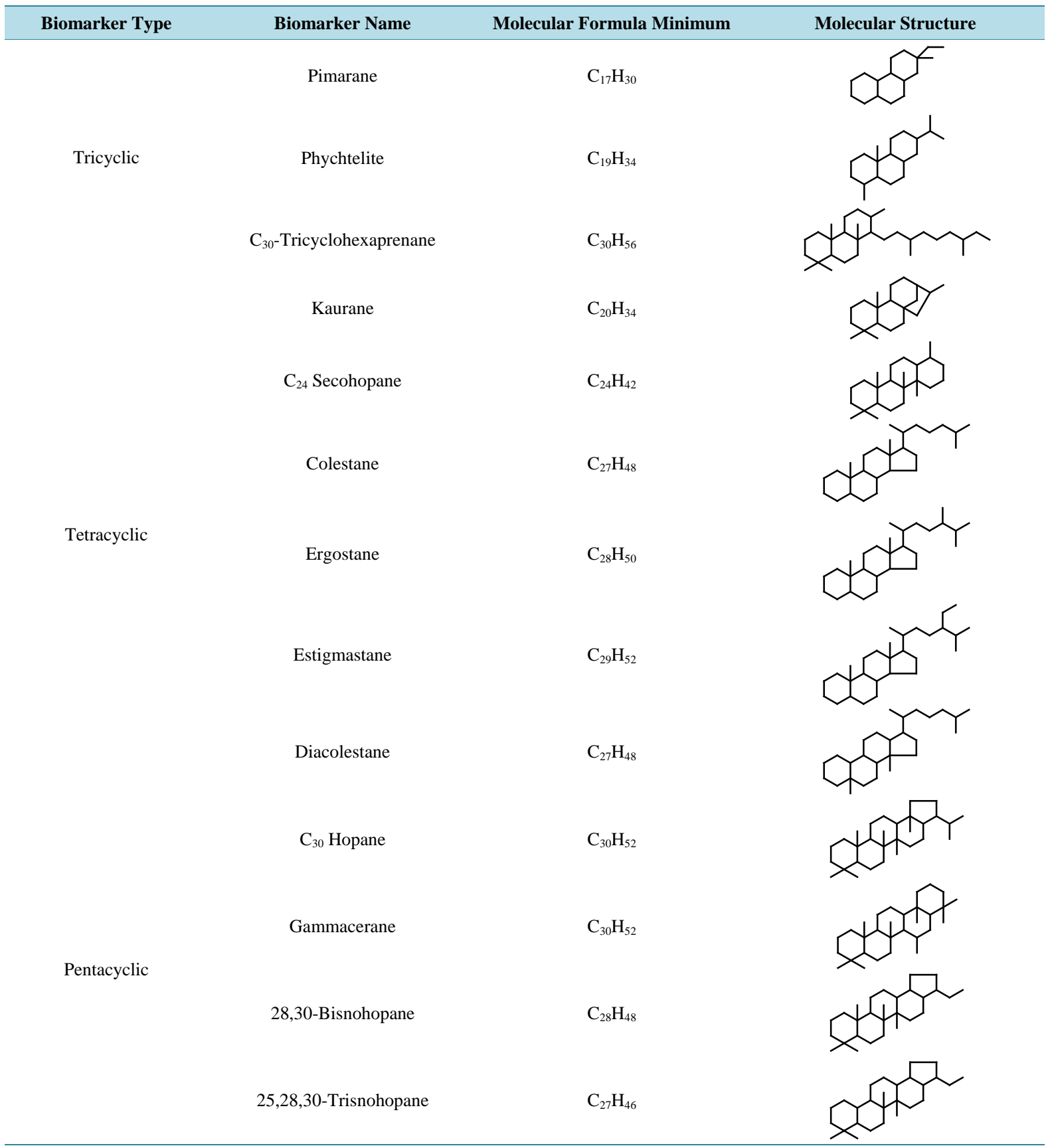

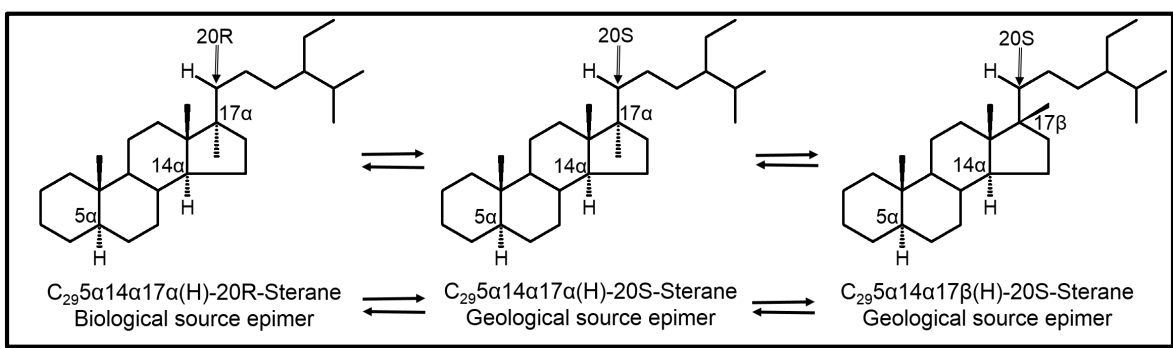

Figure 3. Stereoisomery of $\mathrm{C}_{29}$ steranes [1]. 
Table 4. Priority PAHs indicating the number of aromatic rings, the molecular formula minimum, molecular mass, and the associated health risks.

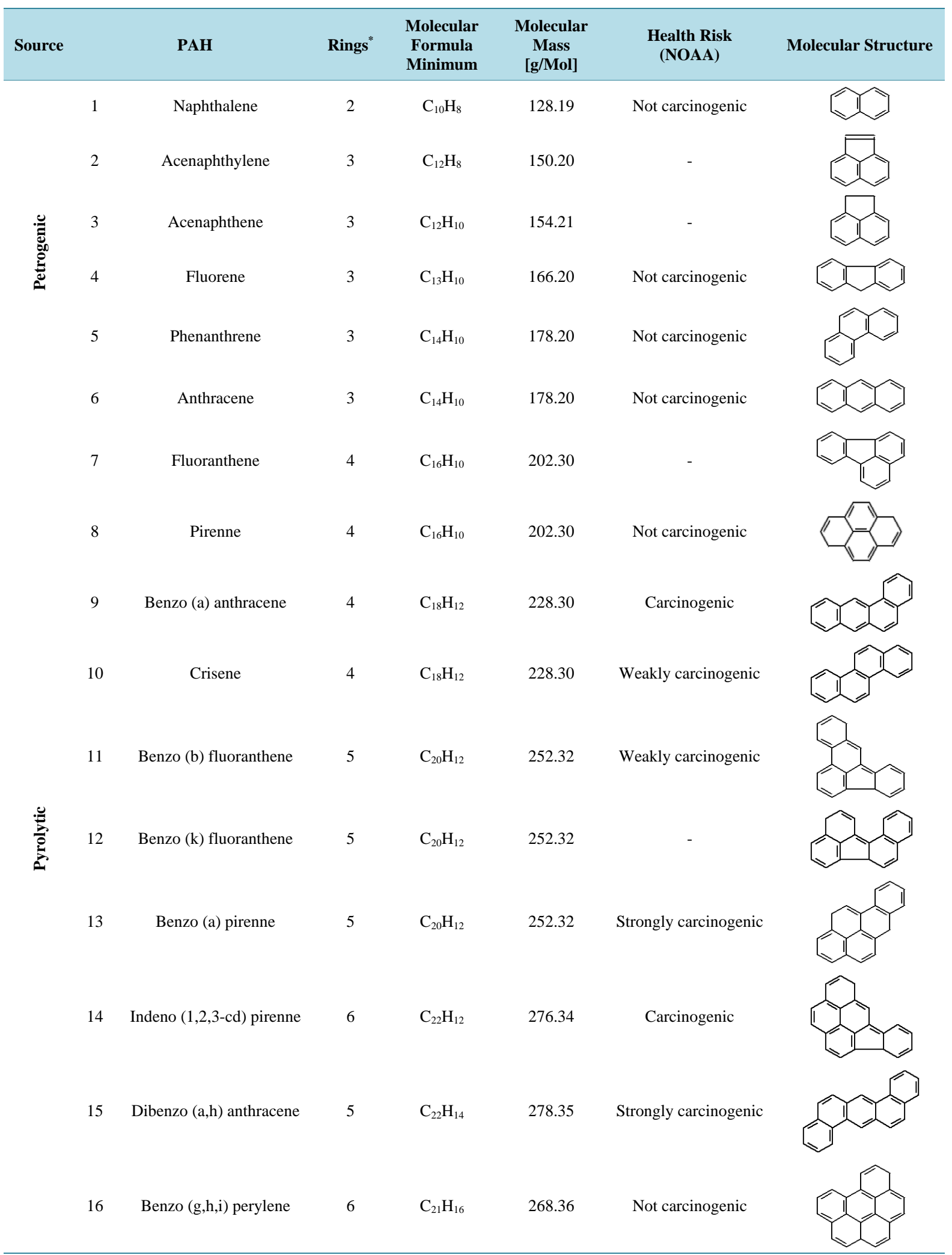

Source: Modified from Veiga, 2003. 


\subsection{Weathering Biomarker}

Oil weathering can be assessed in three different ways: 1) by the presence or absence of oil compounds and biomarkers [60]; 2) by the oil relative molecular abundance e; 3) parametrically, using relations between heights, areas or concentrations of biomarkers and/or compounds of geochemical interest [31] [61] [62]. Weathering processes affect the status of different biomarkers and crude oil compounds [1] [60] and its molecular abundance over indicates deterioration, degradation or weathering level and residence time of certain petroleum. The Figure 4, show some biochemical reactions them occur in the weathering process for biomarker of petroleum. This reaction includes hydrolysis (chemical oxidation and reduction), cracking, metabolization, free radicals formation and others.

\subsection{Biomarker Analyses}

Analytically, biomarkers are detected by gas chromatography coupled to mass spectrometry (GC-MS), using single ion monitoring (SIM) [1] [27] [31] [42] [56] [62] [63]. Is monitoring ion mass-charge $\mathrm{m} / \mathrm{z} 169$ and $\mathrm{m} / \mathrm{z} 197$ to pristane and phytane, $\mathrm{m} / \mathrm{z} 177$ and $\mathrm{m} / \mathrm{z} 191$ for homologous series of tricyclic, for $\mathrm{C}_{30}$-hopane (Figure 5(a)), $\mathrm{T}_{\mathrm{s}}$ and $\mathrm{T}_{\mathrm{m}}$ hopanes, oleanane, gammacerane, and homohopane homologous series $\left(\mathrm{C}_{31}-\mathrm{C}_{35}\right)$ [1] [54] [57] [62] [63]. Steranes are monitored by ions at $\mathrm{m} / \mathrm{z} 217$ and $\mathrm{m} / \mathrm{z} 218$ (Figure 5(b)) [1].

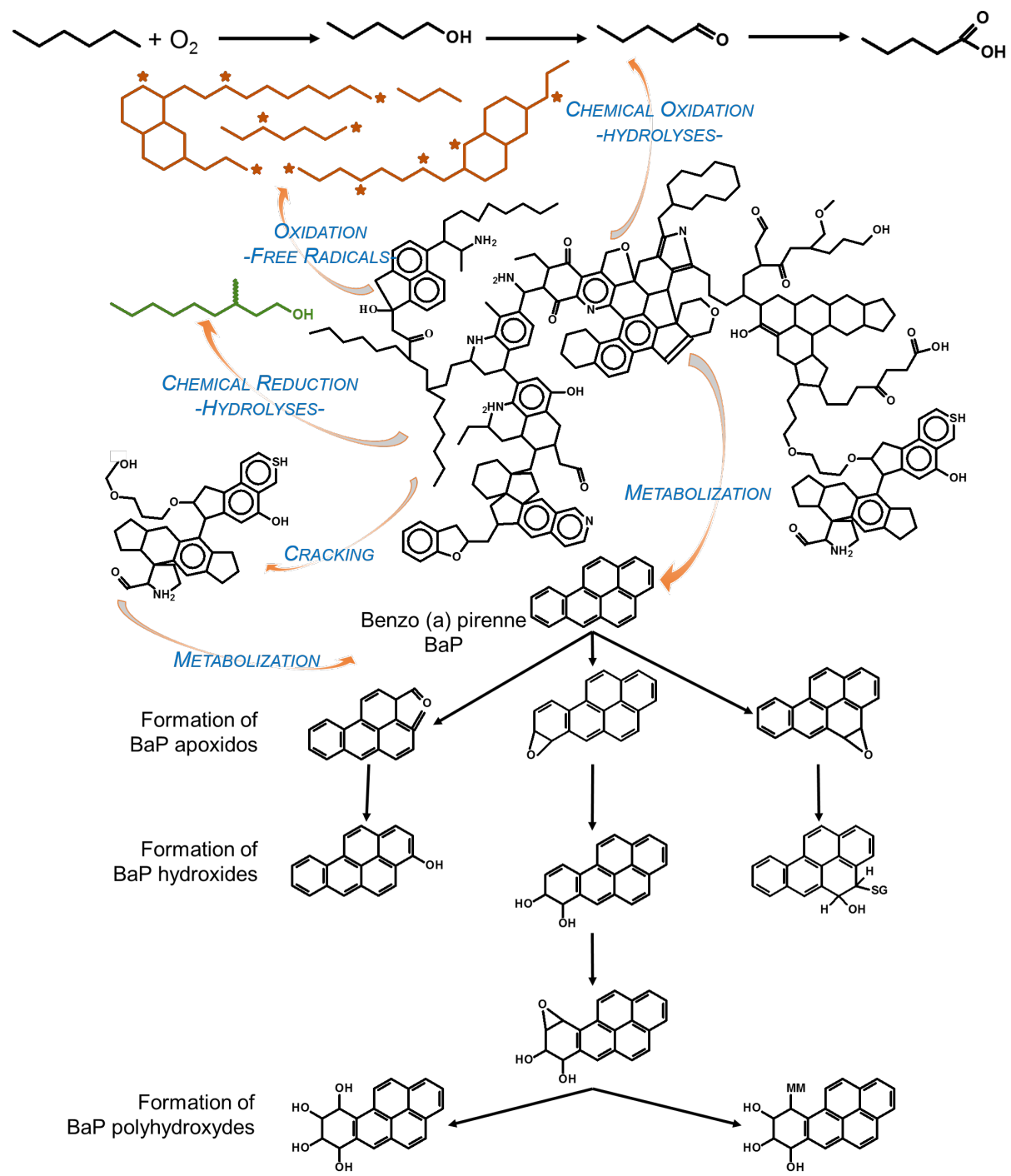

Figure 4. Biomarker weathering and compounds for a sample of petroleum. 


\section{HOPANE}

Ion mass 191.00

$\mathrm{C}_{30}$

\section{TRICYCLICS}

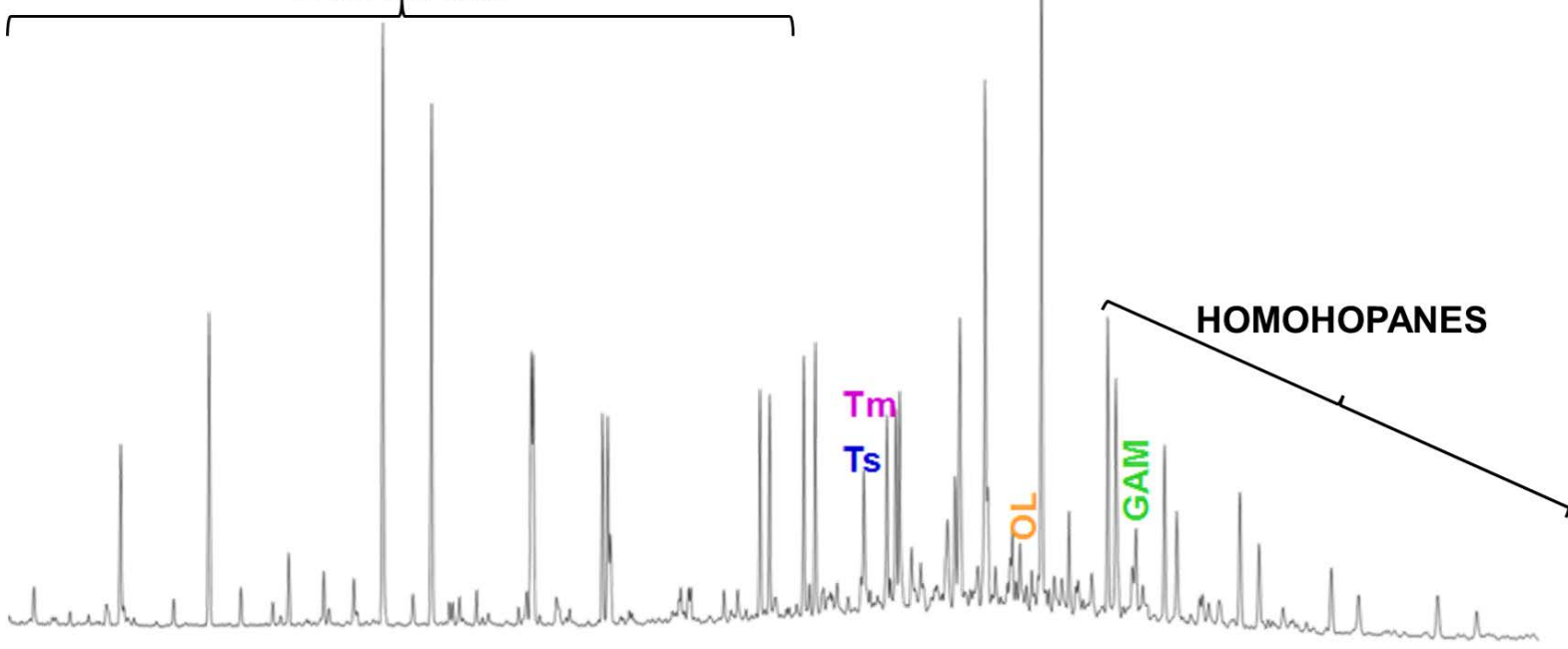

(a)

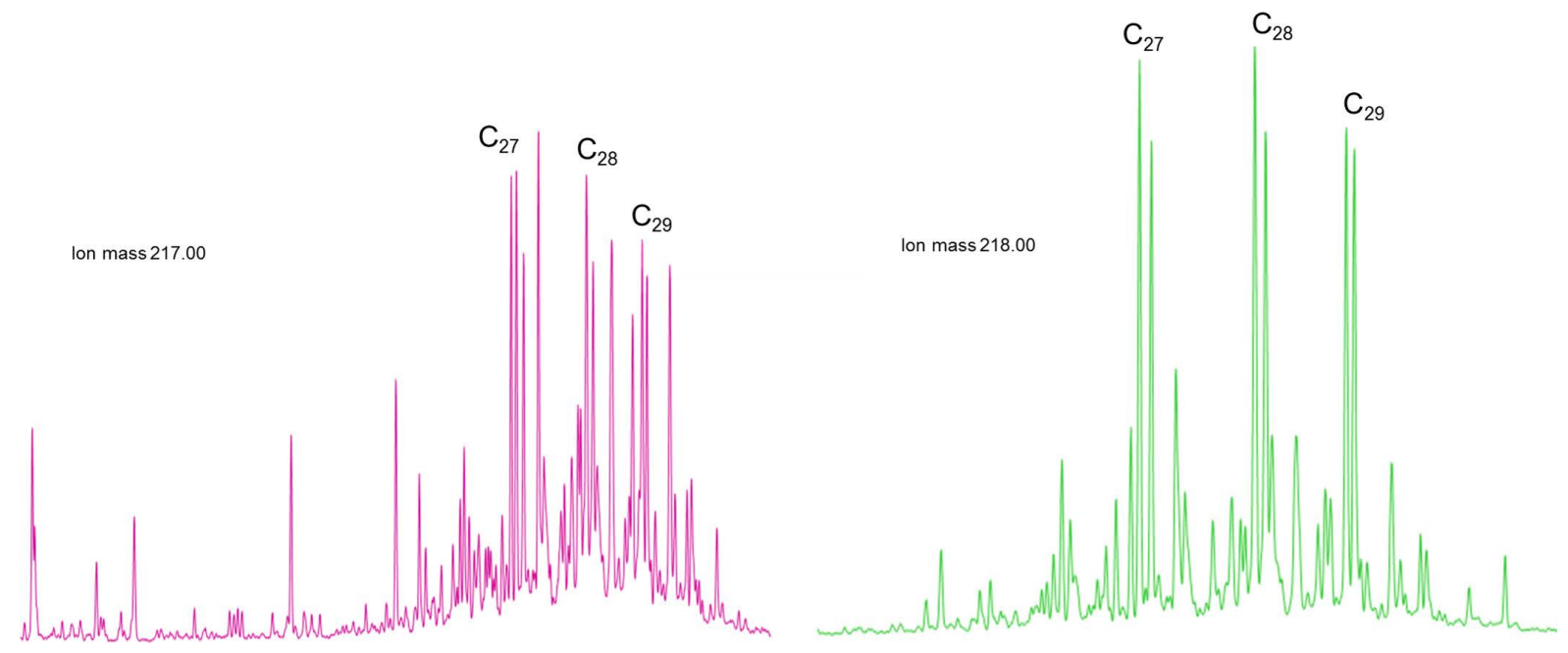

(b)

Figure 5. Fragments for biomarker of petroleum monitoring for GC-MS in SIM mode. (a) Ion fragment $m / z 191$ for petroleum biomarkers: tricyclic homologous series, $T_{s}, T_{m}, C_{30}$-hopane, gammacerane and homologous series of $C_{31}$ to $C_{35}$ homohopanes. $\mathrm{T}_{\mathrm{s}}$ : $\mathrm{C}_{27} 18 \alpha(\mathrm{H})-22,29,30$-trisnorneohopane. $\mathrm{T}_{\mathrm{m}}$ : $\mathrm{C}_{27} 17 \alpha(\mathrm{H})-22,29,30$-trisnorhopane; (b) Fragment ions $\mathrm{m} / \mathrm{z} 217$ and $\mathrm{m} / \mathrm{z} 218$ for $\mathrm{C}_{27}, \mathrm{C}_{28}$, and $\mathrm{C}_{29}$ steranes.

\subsection{Weathering Biomarker Parameters}

Parametrically, the values evaluated in petroleum weathering are the ratios between pristane/ $\mathrm{C}_{17}$, phytane/ $\mathrm{C}_{18}$, pristane/fitane [1] [64], depletion percentage, $\% \mathrm{C}_{27}, \mathrm{C}_{28}, \mathrm{C}_{29}$-steranes, $\mathrm{C}_{30}$-hopane/gammacerane index, $\mathrm{T}_{\mathrm{s}} / \mathrm{T}_{\mathrm{m}}$, stereoisomery index $\mathrm{C}_{29}$-steranes and 22R/22S-homohopane [1] [37] [54] [57]. Some equations are used to assess these relations, and thus estimate the degradation level or weathering of crude oil (Equations (1), (2), (3) and (4)). There are several import parameters that must be calculated in order to check and interpreting the overall weathering process [37] [54] [56] [60] [65]-[67]. 
The depletion percentage evaluates the time the decrease in molecular abundance of specific biomarker, based on the relative abundance of $\mathrm{C}_{30}$-hopano. Where the initial biomarker concentration of interest $\left(\mathrm{A}_{0}\right)$; are measure by the ratio of the initial concentration of $\mathrm{C}_{30}$-hopane $\left(\mathrm{H}_{0}\right)$ at time initial $(0)$. After the spill of the weathered is calculate by the ratio biomarker of interest concentration at time $\left(\mathrm{A}_{t}\right)$ and the concentration the $\mathrm{C}_{30}$-hopane $\left(\mathrm{H}_{\mathrm{t}}\right)$ (Equation (1)) [30].

$$
\text { \%Depletion }=\left(\frac{\mathbf{A}_{0}}{\mathbf{H}_{0}}-\frac{\mathbf{A}_{\mathbf{t}} / \mathbf{H}_{\mathbf{t}}}{\mathbf{A}_{0} / \mathbf{H}_{0}}\right) * 100
$$

The steranes percentage of $\mathrm{C}_{27}, \mathrm{C}_{28}$ and $\mathrm{C}_{29}$-steranes, estimate the weathering process or maturate index for determinate steranes and can be determined by the ratio of esterano study and sum of $\mathrm{C}_{27}, \mathrm{C}_{28}$ and $\mathrm{C}_{29}$ steranes. It is calculated by substituting the $\% \mathrm{C}_{28}$-sterane and $\% \mathrm{C}_{29}$-sterane (Equation (2)) [1] [33] [54].

$$
\% \mathbf{C}_{27}(\text { sterane })=\frac{\mathbf{C}_{27}}{\mathbf{C}_{27}+\mathbf{C}_{28}+\mathbf{C}_{29}} * 100
$$

The $T_{s} / T_{m}$ index possibility the assess input matter, maturity and degradation or weathering. Peters and collages (2005), describe that for particulars cases, $T_{m}$ is more easy degradable then $T_{s}$, so the $T_{s} / T_{m}$ Index increase with the weathering process (Equation (3)) [1] [33] [54].

$$
\mathbf{T}_{\mathrm{s}} / \mathbf{T}_{\mathrm{m}} \text { Index }=\frac{\mathbf{T}_{\mathrm{s}}}{\mathbf{T}_{\mathrm{s}}+\mathbf{T}_{\mathrm{m}}}
$$

Stereoisomerism steranes index determining levels of maturate, degradation, or weathering for mixture racemic the steranes (Figure 3) [1] [33].

$$
\mathrm{C}_{29} \text {-sterane Index }=\frac{\mathrm{C}_{29} \alpha \alpha \alpha(\mathrm{H})-20 \mathrm{~S}}{\mathrm{C}_{29} \alpha \alpha \alpha(\mathrm{H})-20 \mathrm{~S}+\mathrm{C}_{29} \alpha \alpha \alpha(\mathrm{H})-20 \mathrm{R}}
$$

Aromatic biomarkers can be parametrically assessed through different equations in accordance with the aromatic compounds monitored and geochemical interests [1] [8] [24] [33] [48] [68] [69]. Peters et al. (2005) and Veiga (2003) broadly describe the geochemical and parametric use of these compounds.

The data generated will be analyzed in comparison with literature data, and also analyzed statistically, based on the Multivariate Statistics applied to environmental studies and research [39] [65] [66]. Besides the use of descriptive statistical analyzes to achieve the proposed goal will be used the Statistica program for Windows, version 7.0 of the Statsoft Inc. for statistical analysis. Thus, the steps carried out in the statistical treatment of the data will be as following [1] [56] [57] [60]-[63] [65] [66] [70]-[72].

\section{Limitation of the Study}

For aromatic compounds, this review focused on the environmental purpose of the PAHs, more than in the aspect related to the derivative geochemistry description of their molecular abundance in particular oil.

\section{Conclusion}

Assessment, monitoring, and modeling of weathering processes associated with petroleum biomarkers are important tools for geochemistry of petroleum and environment. This allows predicting, with relative certainty, the residence time and what kind of compounds was generated during a probable oil spill, and indicates which kind of technology would be more appropriated to rapidly recover an impacted area or ecosystem. In a scientific view, this study provides technical-scientific knowledge, innovation base needed in processes associated with the petroleum industry and environmental impact studies.

\section{Acknowledgements}

The authors thank the technical team from the NEA (Núcleo de Estudos Ambientais) by the constant support and collaboration in analytical processes and professional areas. We also thank the CNPq, FABESB, FAPEX agencies, and geosciences institute/Federal University of Bahia—IGEO/UFBA by the finance generated for this 
research development, represented in fellowships, reagents, and laboratory materials.

\section{References}

[1] Peters, K.E., Walters, C.C. and Moldowan, J.M. (2005) The Biomarker Guide, Biomarkers and Isotopes in Petroleum Exploration and Earth History, Volume 2. Cambridge University Press, Cambridge.

[2] Tissot, B.P. and Welte, D.H. (1982) Petroleum Formation and Occurrence. A New Approach to Oil and Gas Exploration. Tomos I y II. Consejo Nacional De Ciencia y Tecnología, México.

[3] Cortes, J.E., Niño, J.E., Polo, J.A., Tobo, A.G., Gonzalez, C. and Siachoque, S.C. (2013) Molecular Organic Geochemistry of the Apiay Field in the Llanos Basin, Colombia. Journal of South American Earth Sciences, 47, 166-178. http://dx.doi.org/10.1016/j.jsames.2013.07.007

[4] Uhler, A.D., Stout, S.A. and Douglas, G.S. (2007) Chemical. Heterogeneity in Modern Marine Residual Fuel Oils. Oil Spill Environmental Forensics, Cap. 10, 727-348.

[5] NOAA's. National Ocean Service.

[6] Price, D.G. (1995) Weathering and Weathering Processes. Quarterly Journal of Engineering Geology and Hydrogeology, 28, 243-252. http://dx.doi.org/10.1144/GSL.QJEGH.1995.028.P3.03

[7] Alberdi, M., Moldowan, J.M., Peters, K.E. and Dahl, J.E. (2001) Stereoselective Biodegradation of Tricyclic Terpanes in Heavy Oils from the Bolivar Coastal Fields, Venezuela. Organic Geochemistry, 32, 181-191. http://dx.doi.org/10.1016/S0146-6380(00)00130-3

[8] Barakat, A.O., Quian, Y., Kim, M. and Kennucutt II, M.C. (2001) Compositional Changes of Aromatics Steroid Hydrocarbons in Naturally Weathered Oil Residual in the Egyptian Western Desert. Environment Forensics, 3, 219-225. http://dx.doi.org/10.1080/713848375

[9] Peters, K.E. and Moldowan, J.M. (1991) Effects of Source, Thermal Maturity, and Biodegradation on the Distribution and Isomerization of Homohopanes in Petroleum. Organic Geochemistry, 17, 47-51. http://dx.doi.org/10.1016/0146-6380(91)90039-M

[10] Wang, Z.D., Yang, C., Fingas, M., Hollebone, B., Yim, U.H. and Oh, J.R. (2007) Petroleum Biomarker Fingerprinting for Oil Spill Characterization and Source Identification. Oil Spill Environmental Forensics, Cap. 3, 73-146. http://dx.doi.org/10.1016/B978-012369523-9.50007-0

[11] Oudot, J., Merlinb, F.X. and Pinvidic, P. (1998) Weathering Rates of Oil Components in a Bioremediation Experiment in Estuarine Sediments. Marine Environmental Research, 45, 113-125. http://dx.doi.org/10.1016/S0141-1136(97)00024-X

[12] Yang, Z.Y., Hollebone, B.P., Wang, Z.D., Yang, C. and Landriault, M. (2013) Effect of Storage Period on the Dominant Weathering Processes of Biodiesel and Its Blends with Diesel in Ambient Conditions. Fuel, 104, 342-350. http://dx.doi.org/10.1016/j.fuel.2012.09.001

[13] Cai, M.M., Yao, J., Yang, H.J., Wang, R.X. and Masakorala, K. (2013) Aerobic Biodegradation Process of Petroleum and Pathway of Main Compounds in Water Flooding Well of Dagang Oil Field. Bioresource Technology, 144, 100-106. http://dx.doi.org/10.1016/j.biortech.2013.06.082

[14] Ron, E.Z. and Rosenberg, E. (2014) Enhanced Bioremediation of Oil Spills in the Sea. Current Opinion in Biotechnology, 27, 191-194. http://dx.doi.org/10.1016/j.copbio.2014.02.004

[15] Barakat, A.O., Qianb, Y.R., Kimb, M. and Kennicutt, M.C. (2001) Chemical Characterization of Naturally Weathered Oil Residues in Arid Terrestrial Environment in Al-Alamein, Egypt. Environment International, 27, 291-310. http://dx.doi.org/10.1016/S0160-4120(01)00060-5

[16] Bowden, S.A., Farrimond, P.S., Colin, E. and Love, G.D. (2006) Compositional Differences in Biomarker Constituents of the Hydrocarbon, Resin, Asphaltene and Kerogen Fractions: An Example from the Jet Rock (Yorkshire, UK). Organic Geochemistry, 37, 379-383.

[17] Gallego, J.R., Sierra, C., Villa, R., Peláez, A.I. and Sánchez, J. (2010) Weathering Processes Only Partially Limit the Potential for Bioremediation of Hydrocarbon-Contaminated Soils. Organic Geochemistry, 41, 896-900. http://dx.doi.org/10.1016/j.orggeochem.2010.04.021

[18] Bennett, B., Fustic, M., Farrimond, P., Huang, H.P. and Larter, S.R. (2006) 25-Norhopanes: Formation during Biodegradation of Petroleum in the Subsurface. Organic Geochemistry, 37, 787-797. http://dx.doi.org/10.1016/j.orggeochem.2006.03.003

[19] ITOPF. International Tanker Owners Pollution Federation Limited.

[20] Cortes, J.E., Rincon, J.M., Jaramillo, J.M., Philp, R.P. and Allen, J. (2010) Biomarkers and Compound-Specific Stable Carbon Isotope of $n$-Alkanes in Crude Oils from Eastern Llanos Basin, Colombia. Journal of South American Earth Sciences, 29, 198-213. http://dx.doi.org/10.1016/j.jsames.2009.03.010 
[21] Hackley, P.C., Ryder, R.T., Trippi, M.H. and Alimi, H. (2013) Thermal Maturity of Northern Appalachian Basin Devonian Shales: Insights from Sterane and Terpane Biomarkers. Fuel, 106, 455-462.

http://dx.doi.org/10.1016/j.fuel.2012.12.032

[22] Marynowski, L., Kurkiewicz, S., Rakociński, M. and Simoneit, B.R.T. (2011) Effects of Weathering on Organic Matter: I. Changes in Molecular Composition of Extractable Organic Compounds Caused by Paleoweathering of a Lower Carboniferous (Tournaisian) Marine Black Shale. Chemical Geology, 285, 144-156. http://dx.doi.org/10.1016/j.chemgeo.2011.04.001

[23] Marynowski, L., Szełęg, E., Jędrysek, M.O. and Simoneit, B.R.T. (2011) Effects of Weathering on Organic Matter Part II: Fossil Wood Weathering and Implications for Organic Geochemical and Petrographic Studies. Organic Geochemistry, 42, 1076-1088.

[24] Netto, A.D.P., Moreira, J.C., Ana D., Elisa, X.O., Arbilla, G.., Ferreira, L.F.V., Oliveira, A.S. and Barek, J. (2000) Avaliação da contaminação humana por hidrocarbonetos policíclicos aromáticos (HPAs) e seus derivados nitrados (NHPAs): Uma revisão metodológica. Química Nova, 23, 765-773. http://dx.doi.org/10.1590/S0100-40422000000600010

[25] Harayama, S., Kishira, H., Kasai, Y. and Shutsubo, K. (1999) Petroleum Biodegradation in Marine Environments. Journal Molecular Microbiology Biotechnology, 1, 63-70.

[26] Price, D.G. (1995) Weathering and Weathering Processes. Quarterly Journal of Engineering Geology and Hydrogeology, 28, 243-252. http://dx.doi.org/10.1144/GSL.QJEGH.1995.028.P3.03

[27] Kiepper, A.P., Casilli, A. and Azevedo, D.A. (2014) Depositional Paleoenvironment of Brazilian Crude Oils from Unusual Biomarkers Revealed Using Comprehensive Two Dimensional Gas Chromatography Coupled to Time of Flight Mass Spectrometry. Organic Geochemistry, 70, 62-75. http://dx.doi.org/10.1016/j.orggeochem.2014.03.005

[28] Philp, R.P., Allen, J. and Kuder, T. (2002) The Use of the Isotopic Composition of Individual Compounds for Correlating Spilled Oils and Refined Products in the Environment with Suspected Sources. Environmental Forensics, 3, 341 348. http://dx.doi.org/10.1006/enfo.2002.0104

[29] Joo, C., Shim, W.J., Kim, G., Ha, S.Y., Moonkoo, A., Kima, J.G., Kim, E., Beom, J., Seung, W., Kim, Y.-O. and Yim, U.H. (2013) Mesocosm Study on Weathering Characteristics of Iranian Heavy Crude Oil with and without Dispersants. Journal of Hazardous Materials, 248-249, 37-46.

[30] Braddock, J.F., Lindstrom, J.E. and Prince, R.C. (2003) Weathering of a Subarctic Oil Spill over 25 Years: The Caribou-Poker Creeks Research Watershed Experiment. Cold Regions. Science and Technology, 37, 11-23.

[31] Faksness, L.-G., Brandvik, P.J., Daae, R.L., Leirvik, F. and Børseth, J.F. (2011) Large-Scale Oil-in-Ice Experiment in the Barents Sea: Monitoring of Oil in Water and Metocean Interactions. Marine Pollution Bulletin, 62, 976-984. http://dx.doi.org/10.1016/j.marpolbul.2011.02.039

[32] Radović, J.R., Aeppli, C., Nelson, R.K., Jimenez, N., Reddy, C.M., Bayona, J.M. and Albaigés, J. (2014) Assessment of Photochemical Processes in Marine Oil Spill Fingerprinting. Marine Pollution Bulletin, 79, 268-277.

[33] Burns, K.A., Codi, S. and Duke, N.C. (2000) Gladstone, Australia Field Studies: Weathering and Degradation of Hydrocarbons in Oiled Mangrove and Salt Marsh Sediments with and without the Application of Experimental Bioremediation Protocol. Marine Pollution Bulletin, 41, 392-402.

[34] Cai, M.M., Yao, J., Yang, H.J., Wang, R.X. and Masakorala, K. (2013) Aerobic Biodegradation Process of Petroleum and Pathway of Main Compounds in Water Flooding Well of Dagang Oil Field. Bioresource Technology, 144, 100-106. http://dx.doi.org/10.1016/j.biortech.2013.06.082

[35] Cassia, O.F., Claudia, H., Wagener, A.L.R. and Scofield, A.L. (2008) Origin and Degradation of Hydrocarbons in Mangrove Sediments (Rio de Janeiro, Brazil) Contaminated by an Oil Spill. Organic Geochemistry, 39, 289-307.

[36] Fonseca, S.A.R. (2009) Análise De estratégias de contingência ao derramamento de óleo: Estudo de caso do Campo de Golfinho, Espírito Santo-Brasil. 2009. Monografia: Graduação em Oceanografia do Departamento de Oceanografia e Ecologia. Universidade Federal do Espírito Santo. Centro de Ciências Humanas e Naturais. Departamento de Oceanografia e Ecologia. Graduação em Oceanografia, Vitória.

[37] Burns, K.A., Codi, S., Pratt, C. and Duke, N.C. (1999) Weathering of Hydrocarbons in Mangrove Sediments: Testing the Effects of Using Dispersants to Treat Oil Spills. Organic Geochemistry, 30, 1273-1286. http://dx.doi.org/10.1016/S0146-6380(99)00101-1

[38] Fernández-Varela, R., Andradea, J.M., Muniateguia, S., Prada, D. and Ramírez-Villalobos, F. (2009) The Comparison of Two Heavy Fuel Oils in Composition and Weathering Pattern, Based on IR, GC-FID and GC-MS Analyses: Application to the Prestige Wreackage. Water Research, 43, 1015-1026. http://dx.doi.org/10.1016/j.watres.2008.11.047

[39] Fingas, M.F. (1995) A Literature Review of the Physics and Predictive Modelling of Oil Spill Evaporation. Journal of Hazardous Materials, 42, 157-175. http://dx.doi.org/10.1016/0304-3894(95)00013-K

[40] López, L. (2013) Study of the Biodegradation Levels of Oils from the Orinoco Oil Belt (Junin Area) Using Different 
Biodegradation Scales. Organic Geochemistry, 66, 60-69. http://dx.doi.org/10.1016/j.orggeochem.2013.10.014

[41] API. American Petroleum Institute. http://www.api.org/

[42] Barakat, A.O., Mostafa, A.R., Qian, Y.R. and Kennicutt, M.C. (2002) Application of Petroleum Hydrocarbon Chemical Fingerprinting in Oil Spill Investigations-Gulf of Suez, Egypt. Spill Science \& Technology Bulletin, 7, $229-239$. http://dx.doi.org/10.1016/S1353-2561(02)00039-7

[43] Esler, D., Ballachey, B.E., Trust, K.A., Iverson, S.A., Reed, J.A., Miles, A.K., Henderson, J.D., Woodin, B.R., Stegeman, J.J., Mcadie, M., Mulcahy, D.M. and Wilson, B.W. (2011) Cytochrome P4501A Biomarker Indication of the Timeline of Chronic Exposure of Barrow’s Goldeneyes to Residual Exxon Valdez Oil. Marine Pollution Bulletin, 62, 609-614. http://dx.doi.org/10.1016/j.marpolbul.2010.11.015

[44] Wang, Z.D., Yang, C., Kelly-Hooper, F., Hollebone, B.P., Peng, X., Brown, C.E., Landriault, M., Sun, J. and Yang, Z. Forensic Differentiation of Biogenic Organic Compounds from Petroleum Hydrocarbons in Biogenic and Petrogenic Compounds Cross-Contaminated Soils and Sediments. Journal of Chromatography, 1216, 1174-1191.

[45] Brocks, J.J. and Summons, R.E. (2003) Sedimentary Hydrocarbons, Biomarkers for Early Life. Tratise on Geochemistry, 8, 63-115. http://dx.doi.org/10.1016/B0-08-043751-6/08127-5

[46] Nazir, A. and Fazeelat, T. (2014) Petroleum Geochemistry of Lower Indus Basin, Pakistan: I. Geochemical Interpretation and Origin of Crude Oils. Journal of Petroleum Science and Engineering, 122, 173-179. http://dx.doi.org/10.1016/j.petrol.2014.07.008

[47] Xiao, F., Liu, L.F., Zhang, Z.H., Wu, K.J., Xu, Z.J. and Zhou, C.X. (2014) Conflicting Sterane and Aromatic Maturity Parameters in Neogene Light Oils, Eastern Chepaizi High, Junggar Basin, NW China. Organic Geochemistry, 76, 4861. http://dx.doi.org/10.1016/j.orggeochem.2014.07.014

[48] Barbanti, S.M., Moldowan, J.M., Watt, D.S. and Kolaczkowska, E. (2011) New Triaromatics Steroids Distinguish Paleozoic from Mesozoic Oil. Organic Geochemistry, 42, 409-424. http://dx.doi.org/10.1016/j.orggeochem.2011.02.007

[49] Barakat, A.O., Mostafa, A.R., Rullkötter, J. and Hegaz, A.R. (1999) Application of a Multimolecular Marker Approach to Fingerprint Petroleum Pollution in the Marine Environment. Marine Pollution Bulletin, 38, 535-544. http://dx.doi.org/10.1016/S0025-326X(98)00110-6

[50] Bence, A.E., Page, D.S. and Boehm, P.D. (2007) Advances in Forensic Techniques for Petroleum Hydrocarbons: The Exxon Valdez Experience. Oil Spill Environmental Forensics, 2007, 449-487.

[51] Boehm, P.D., Douglas, G., Burns, S.W.A., Mankiewicz, P.J., Page, D.S. and Bence, A.E. (1997) Application of Petroleum Hydrocarbon Chemical Fingerprinting and Allocation Techniques after the Exxon Valdez Oil Spill. Marine Pollution Bulletin, 34, 599-613. http://dx.doi.org/10.1016/S0025-326X(97)00051-9

[52] Wu, Y.Q., Xia, Y.Q., Wang, Y.L., Lei, T.Z., Chang, J. and Wang, Y.X. (2013) Distribution and Properties of Biomarkers in Severely Biodegraded Crude Oil of Gudao Reservoir, China. Journal of Petroleum Science and Engineering, 103, 97-105. http://dx.doi.org/10.1016/j.petrol.2013.02.003

[53] Nytoft, H.P. and Bojesen-Koefoed, J.A. (2001) 17 $\alpha, 21 \alpha(\mathrm{H})$-Hopanes: Natural and Synthetic. Organic Geochemistry, 32, 841-856. http://dx.doi.org/10.1016/S0146-6380(01)00028-6

[54] Bost, F.D., Frontera-Suau, R., Mcdonald, T.J., Peters, K.E. and Morris, P.J. (2001) Aerobic Biodegradation of Hopanes and Norhopanos in Venezuelan Crude Oils. Organic Geochemistry, 32, 105-114. http://dx.doi.org/10.1016/S0146-6380(00)00147-9

[55] Peters, K.E., Moldowan, J.M., Lacroce, M.V. and Kubicki, J.D. (2014) Stereochemistry, Elution Order and Molecular Modeling of Four Diaergostanes in Petroleum. Organic Geochemistry, 76, 1-8. http://dx.doi.org/10.1016/j.orggeochem.2014.07.008

[56] Mulabagal, V., Yin, F., John, G.F., Hayworth, J.S. and Clement, T.P. (2013) Chemical Fingerprinting of Petroleum Biomarkers in Deepwater Horizon Oil Spill Samples Collected from Alabama Shoreline. Marine Pollution Bulletin, 70, 147-154. http://dx.doi.org/10.1016/j.marpolbul.2013.02.026

[57] Peters, K.E. (2000) Petroleum Tricyclic Terpanes: Predicted Physicochemical Behavior from Molecular Mechanics Calculations. Organic Geochemistry, 31, 497-507. http://dx.doi.org/10.1016/S0146-6380(00)00029-2

[58] Turner, R.E., Overton, E.B., Meyer, B.M., Miles, M.S. and Hooper-Bui, L. (2014) Changes in the Concentration and Relative Abundance of Alkanes and PAHs from the Deepwater Horizon Oiling of Coastal Marshes. Marine Pollution Bulletin, 86, 291-297. http://dx.doi.org/10.1016/j.marpolbul.2014.07.003

[59] Veiga, I.G. (2003) Avaliação da origem dos hidrocarbonetos em sedimentos superficiais de manguezais da região norte da Baía de Todos os Santos/Bahia. Dissertação: Mestrado em Engenharia de Reservatório e de Exploração. Universidade Estadual do Norte Fluminense-UENF. Laboratório de Engenharia e Exploração e Petróleo-LENEP. Macaé—RJ. Dezembro-2003.

[60] Wang, Z. and Stout, S.A. (2007) Oil Spill Environmental Forensics. Fingerprint and Source Identification. Academic 
Press, Waltham.

[61] Douglas, G.S., Emsbo-Mattingly, S.D., Stout, S.A., Uhler, A.D. and Mccarthy, K.J. (2007) Chemical Fingerprinting Methods. In: Murphy, B. and Morrison, R., Eds., Introduction to Environmental Forensics, Academic Press, New York, 311-469.

[62] Wang, C.Y., Chen, B., Zhang, B.Y., He, S.J. and Zhao, M.M. (2013) Fingerprint and Weathering Characteristics of Crude Oils after Dalian Oil Spill, China. Marine Pollution Bulletin, 71, 64-68. http://dx.doi.org/10.1016/j.marpolbul.2013.03.034

[63] Wang, Z.D., Fingas, M. and Page, D.S. (1999) Oil Spill Identification. Journal of Chromatography A, 843, 369-411.

[64] Dawson, K.S., Schaperdoth, I., Freeman, K.H. and Macalady, J.L. (2013) Anaerobic Biodegradation of the Isoprenoid Biomarkers Pristane and Phytane. Organic Geochemistry, 65, 118-126. http://dx.doi.org/10.1016/j.orggeochem.2013.10.010

[65] Christensen, J.H. and Tomasi, G. (2007) Practical Aspects of Chemometrics for Oil Spill Fingerprinting. Journal of Chromatography, 1169, 1-22. http://dx.doi.org/10.1016/j.chroma.2007.08.077

[66] Sebastião, P. and Soares, C.G. (1995) Modeling the Fate of Oil Spills at Sea. Spill Science \& Technology Bulletin, 2, 121-131.

[67] Killops, S., Stoddart, D. and Mills, N. (2014) Inferences for Sources of Oils from the Norwegian Barents Sea Using Statistical Analysis of Biomarkers. Organic Geochemistry, 76, 157-166. http://dx.doi.org/10.1016/j.orggeochem.2014.07.011

[68] Bejarano, A.C. and Michel, J. (2010) Large-Scale Risk Assessment of Polycyclic Aromatic Hydrocarbons in Shoreline Sediments from Saudi Arabia: Environmental Legacy after Twelve Years of the Gulf War Oil Spill. Environmental Pollution, 158, 1561-1569. http://dx.doi.org/10.1016/j.envpol.2009.12.019

[69] Brocks, J.J., Love, J.D., Snape, C.E., Logan, G.A., Summons, R.E. and Buick, R. (2003) Release of Bound Aromatic Hydrocarbons from Late Archean and Mesoproterozoic kerogens via Hydropyrolysis. Geochimica et Cosmochimica Acta, 67, 1521-1530. http://dx.doi.org/10.1016/S0016-7037(02)01302-9

[70] Wang, Z.D., Li, K., Fingas, M., Sigouin, L. and Ménard, L. (2002) Characterization and Source Identification of Hydrocarbons in Water Samples Using Multiple Analytical Techniques. Journal of Chromatography, 971, 173-184. http://dx.doi.org/10.1016/S0021-9673(02)01003-8

[71] Ezra, S., Feinstein, S., Pelly, I., Bauman, D. and Miloslavsky, I. (2011) Weathering of Fuel Oil Spill on the East Mediterranean Coast, Ashdod, Israel. Organic Geochemistry, 31, 1733-1741.

[72] Li, N.X., Huang, H.P., Jiang, W.L., Wu, T. and Sun, J.J. (2014) Biodegradation of 25-Norhopanes in a Liaohe Basin (NE China) Oil Reservoir. Organic Geochemistry, 78, 33-43. 